\title{
Smad4-dependent pathways control basement membrane deposition and endodermal cell migration at early stages of mouse development
}

\author{
Ita Costello ${ }^{1}$, Christine A Biondi ${ }^{1}$, Jennifer M Taylor ${ }^{2,3}$, Elizabeth K Bikoff ${ }^{1}$ \\ and Elizabeth J Robertson*1
} \author{
Mountain ACT 2601, Australia \\ Email: Ita Costello - Ita.Costello@path.ox.ac.uk; Christine A Biondi - christine.biondi@uqconnect.edu.au; \\ Jennifer M Taylor - Jen.Taylor@csiro.au; Elizabeth K Bikoff - Elizabeth.Bikoff@path.ox.ac.uk; \\ Elizabeth J Robertson* - Elizabeth.Robertson@path.ox.ac.uk \\ * Corresponding author
}

Address: ${ }^{1}$ Sir William Dunn School of Pathology, University of Oxford, South Parks Road, Oxford, OX1 3RE, UK, ${ }^{2}$ Wellcome Trust Centre for Human Genetics, University of Oxford, Oxford, OX3 7BN, UK and ${ }^{3}$ CSIRO Plant Industry, Black Mountain Laboratories, Clunies Ross Street, Black

Published: 22 October 2009

BMC Developmental Biology 2009, 9:54 doi:10.1/86/147|-2/3X-9-54

This article is available from: http://www.biomedcentral.com/I47|-2/3X/9/54

(c) 2009 Costello et al; licensee BioMed Central Ltd.

This is an Open Access article distributed under the terms of the Creative Commons Attribution License (http://creativecommons.org/licenses/by/2.0), which permits unrestricted use, distribution, and reproduction in any medium, provided the original work is properly cited.

\begin{abstract}
Background: Smad4 mutant embryos arrest shortly after implantation and display a characteristic shortened proximodistal axis, a significantly reduced epiblast, as well as a thickened visceral endoderm layer. Conditional rescue experiments demonstrate that bypassing the primary requirement for Smad4 in the extra-embryonic endoderm allows the epiblast to gastrulate. Smad4independent TGF- $\beta$ signals are thus sufficient to promote mesoderm formation and patterning. To further analyse essential Smad4 activities contributed by the extra-embryonic tissues, and characterise Smad4 dependent pathways in the early embryo, here we performed transcriptional profiling of Smad4 null embryonic stem (ES) cells and day 4 embryoid bodies (EBs).
\end{abstract}

Results: Transcripts from wild-type versus Smad4 null ES cells and day 4 EBs were analysed using Illumina arrays. In addition to several known TGF- $\beta /$ BMP target genes, we identified numerous Smad4-dependent transcripts that are mis-expressed in the mutants. As expected, mesodermal cell markers were dramatically down-regulated. We also observed an increase in non-canonical potency markers (Pramel7, Tbx3, Zscan4), germ cell markers (Aire, Tuba3a, Dnmt3I) as well as early endoderm markers (Dpp4, HI9, Dcn). Additionally, expression of the extracellular matrix (ECM) remodelling enzymes Mmp/4 and Mmp9 was decreased in Smad4 mutant ES and EB populations. These changes, in combination with increased levels of laminin alphal, cause excessive basement membrane deposition. Similarly, in the context of the Smad4 null E6.5 embryos we observed an expanded basement membrane (BM) associated with the thickened endoderm layer.

Conclusion: Smad4 functional loss results in a dramatic shift in gene expression patterns and in the endodermal cell lineage causes an excess deposition of, or an inability to breakdown and remodel, the underlying BM layer. These structural abnormalities probably disrupt reciprocal signalling between the epiblast and overlying visceral endoderm required for gastrulation. 


\section{Background}

Members of the TGF- $\beta$ super-family of secreted growth factors activate a cell surface receptor complex comprised of two distinct transmembrane serine/threonine kinases that, upon ligand binding, phosphorylate members of the downstream receptor-associated Smads (R-Smads) (reviewed by [1]). The closely related R-Smads, Smad2 and Smad3 are phosphorylated in response to TGF- $\beta$ s, Activin and Nodal signals. Smad1, Smad5 and Smad8 transmit BMP and GDF signals. The phosphorylated RSmads in association with the common mediator Smad, Smad4, recruit additional cofactors to form higher order complexes that regulate target gene expression (reviewed by [2]). Smad4, originally discovered as a tumour suppressor gene, shares overall structural features with the RSmads. However, its MH2 domain lacks the C-terminal SXS motif required for receptor-mediated phosphorylation. Smad4-RSmad complexes control a diverse array of biological processes, including cell proliferation, differentiation and cell survival during development and adult tissue homeostasis.

In the early embryo, reciprocal signalling between the epiblast, extra-embryonic ectoderm (ExE) and the overlying visceral endoderm (VE) is responsible for axis patterning and specification of the germ layers (reviewed by $[3,4]$ ). Members of the TGF- $\beta /$ Nodal and BMP subfamilies act as morphogens that control cell differentiation in a concentration dependent manner. Nodal signals from the epiblast promote the formation of the distal visceral endoderm (DVE) $[5,6]$. This specialised cell population migrates anteriorly to become the anterior visceral endoderm (AVE) [7]. Expression of the Nodal antagonists Lefty 1 and Cer 1 by the AVE, is essential for patterning the underlying anterior epiblast [8]. On the posterior side of the embryo, BMP signals from the ExE together with Nodal signals from the epiblast promote primitive streak formation and mesoderm induction [9-12]. Continued Nodal signalling during gastrulation instructs epiblast cells passing through the anterior primitive streak to become definitive endoderm, prechordal plate, node and notochord [13]. Signalling via the BMP pathway is also crucial in early embryonic development (reviewed by $[14,15])$. Genetic studies demonstrate that activities of closely regulated R-Smads modulate dose-dependent Nodal and BMP signals in the early embryo $[11,16]$.

Smad4 null embryos arrest shortly after implantation due to defects in the extra-embryonic lineages [17-19]. The mutants have a shortened proximodistal (P-D) axis, fail to acquire initial anterior-posterior (A-P) polarity, cannot gastrulate and are severely disorganised by E6.5. Early studies attributed the lethality to global proliferative defects $[17,18]$ but conditional rescue experiments demonstrate that TGF- $\beta$ signalling pathways in the embryo proper are surprisingly Smad4-independent [19]. Thus mutant epiblasts, in response to cues from wild-type extra-embryonic tissues, are able to gastrulate and generate diverse mesodermal derivatives $[17,19]$, including the allantois, a rudimentary heart and mid-streak derivatives such as the somites and lateral plate mesoderm. Thus, early A-P axis formation and mesodermal patterning are unaffected. However, Smad4 is required for specification of the anterior primitive streak (APS) derivatives including the prechordal plate, node, notochord and definitive endoderm. Smad4 is also essential for BMP-dependent primordial germ cell (PGC) formation [19].

To investigate Smad4 requirements at early stages of embryonic development, here we exploited Smad4 null ES cells in transcriptional profiling experiments. We compared gene expression patterns in undifferentiated wildtype and mutant ES cells as well as embryoid bodies (EBs). The list of up- or down-regulated genes includes several previously described TGF- $\beta / \mathrm{BMP} / \mathrm{Smad}$ targets. As expected, Smad4 mutant EBs show a marked decrease in gastrulation markers. The mutants display increased expression of several non-canonical potency markers, germ cell markers and early endoderm markers. Interestingly, Smad4 functional loss results in increased laminin expression and decreased expression of matrix metalloproteinases (Mmps). Mutant EBs display thickened endoderm, an expanded basement membrane layer and exhibit defective migratory properties. Collectively these results demonstrate that Smad4-dependent transcriptional regulation controls development of the extra-embryonic endoderm cell lineage.

\section{Results}

Transcriptional profiling of Smad4 null ES cells and EBs

To identify developmentally regulated transcripts that are potentially mis-regulated in the absence of Smad4, we analysed ES cells grown in the presence of LIF, or induced to differentiate as EBs in suspension culture. We compared mRNA expression patterns of wild-type and Smad4 null ES cells and day 4 EBs using the Illumina array platform. We utilised two independent 129S9/SvEvH wildtype (CCE/CCB) [20] and Smad4 null (FNN/BNN) ES cell lines [19]. After 4 days of suspension culture the outer cells of EBs are induced to differentiate to form a layer of primitive endoderm, while a sub-population of inner cells express nascent mesodermal markers. These cell aggregates closely resemble and share many characteristics of E6.5 embryos, the stage when growth defects become evident in Smad4 null mutants. Genes that displayed a 1.5 fold change and a statistical significance to $\mathrm{p}<0.01$ (corrected for multiple testing) were considered as differentially expressed. In Smad4 null ES cells, 243 probe sets detected transcripts up-regulated and 424 down-regulated, while in the EBs 674 and 464 probe sets detected 
increased and decreased transcript expression, respectively. Representative results are summarised in Table 1 and Table 2. The complete list of the mis-regulated genes is available in Additional Files 1 and 1. Data from the micro-arrays was validated using quantitative real-time PCR (Q-PCR) and analysed using the $\Delta \Delta$ CT method [21].

Numerous components of the TGF- $\beta$ pathway are mis-regulated in Smad4 deficient cells including ligands (Gdf1, Tgfb2, Lefty1/2), as well as known target genes (Id1/2/3 and Msx1) (Table 1). The Id family of proteins regulate cell proliferation and differentiation in response to BMP signals $[22,23]$. Id 1, Id 2 and Id 3 are selectively down-regulated in cardiac neural crest cells in conditional Smad4 mutants [24]. Up-regulated Id gene expression in response to BMP signalling is required to sustain selfrenewal and pluripotency under serum-free conditions [25]. Here, loss of Smad4 function in ES cells and EBs results in reduced expression of Id1, Id2 and Id3 family members (Table 1). Western blots similarly reveal that Id1 protein levels are reduced by roughly 7 -fold (Figure 1A).

Expression of $M s x 1$, a Bmp responsive transcription factor, previously identified as a Bmp4 target in ES cells [26], is also down-regulated (Table $1 ;[19])$. The Lefty proteins act as competitive inhibitors of Nodal and antagonise signalling via interactions with Nodal, as well as EGF-CFC coreceptors such as Cripto $[27,28]$. Lefty 1 and Lefty 2 expression is activated in response to Nodal/Activin signals $[29,30]$. Here we observe decreased Lefty 1 and Lefty 2 expression levels due to loss of Smad4 (Table 1). Collectively these results demonstrate that $\operatorname{Smad} 4$ controls expression of several known TGF $\beta /$ BMP target genes and suggest that this array platform offers a promising approach to characterise Smad4-dependent transcriptional networks that regulate early embryonic development.

\section{Increased steady state levels of phosphorylated receptor Smads}

Smad4 deficient pancreatic carcinoma cell lines express increased levels of phosphorylated Smad2 (P-Smad2) [31]. However, in contrast, P-Smad2 levels were unaffected by Smad4 knock down in HaCaT cells [32]. We decided to compare basal TGF- $\beta /$ BMP signalling in wildtype and Smad4 mutant ES cells. As shown in Figure 2, wild-type (CCE \& CCB) and Smad4 null ES cells (FNN \& $\mathrm{BNN}$ ) express roughly equivalent steady-state levels of Smad2/3. However under normal culture conditions, in the absence of exogenous TGF- $\beta$ ligands, Smad 4 mutant ES cells constitutively express 2-2.5 fold more phosphoSmad2 in comparison with wild-type (Figure 2A). Similarly, loss of Smad4 has no effect on steady-state levels of effectors of the Bmp pathway, Smad1 and Smad5. However, we observed increased levels of P-Smad1/5/8 R-
Smads (Figure 2B). Thus Smad4 loss results in increased phosphorylation of both categories of R-Smads. In contrast, phosphorylated Erk1/2 levels remain unchanged in the absence of Smad4 expression (Figure 2B).

\section{Mis-expression of non-canonical potency genes and germ cell markers}

Smad4 null E6.5 embryos strongly express Oct4 [19]. Consistent with this, expression levels of the canonical core stem cell markers, Oct4, Nanog and Sox2 are unaffected in Smad4 mutant ES cells. However, numerous early embryonic and stem cell markers, including Pramel7, $T b x 3$ and Zscan4, are consistently up-regulated in Smad4 mutant ES cells (Table 2). Pramel7 is normally expressed at morula stages and is restricted to the inner cell mass of early blastocysts [33]. Pramel7 over-expression promotes LIF-independent self-renewal [33]. While transcripts are barely detectable in WT ES cells [34], Pramel7 expression increased roughly 6-fold in Smad4 mutant ES cells. Similarly, Tbx3, previously identified as a direct target of BMP Smads [35], is also up-regulated. Tbx3 plays an essential role in stem cell self-renewal and enforced expression represses mesodermal cell lineage commitment [36]. The zinc finger protein Zscan4 is normally expressed in late 2cell embryos and a subpopulation of ES cells [37]. Previous experiments demonstrate Zscan4 is essential for preimplantation development [37] and controls ES cell pluripotency [38]. Here we observed over 2-fold increased expression of Zscan4 in both mutant ES cells and EBs.

Rhox5/Pem, an X-linked homeodomain-containing gene, is up-regulated in mutant EBs. Rhox5 is normally expressed in morula and early blastocyst stage embryos, but shortly after implantation expression becomes restricted to extra-embryonic lineages, specifically the VE and extra-embryonic ectoderm (ExE) [39]. Interestingly, Rhox 5 is normally expressed in ES cells, but is not detected in the primitive ectoderm [39] and Rhox 5 over-expression inhibits ES cell differentiation $[33,40]$. Thus, Rhox5 function maintains early stem cell populations and promotes development of the extra-embryonic cell lineages. Collectively these results demonstrate that Smad4-dependent signalling regulates expression of potency genes.

Germ cell specification in response to $\mathrm{BMP} / \mathrm{Smad}$ signals is strictly Smad4-dependent. Interestingly, expression of several germ cell markers was increased (Table 2). E2F6, which associates with polycomb group complexes, plays an important role in repressing meiosis-specific genes, including Tuba3a and Smc1 [41,42]. These E2F6 target genes are also mis-expressed in Smad4 deficient cells. These results strengthen the idea that Smad4-dependent signals regulate transcriptional networks upstream of early cell fate decisions. 
Table I: Down-regulated genes in Smad4 null ES cells andlor day 4 embryoid bodies

\begin{tabular}{|c|c|c|c|c|c|c|c|c|c|}
\hline \multicolumn{4}{|c|}{ Down-regulated } & \multicolumn{3}{|c|}{ Embryonic Stem Cell Array } & \multicolumn{3}{|c|}{ Day 4 Embryoid Body Array } \\
\hline Gene ID & Gene Description & RefSeq & Chr & $\begin{array}{l}\text { ES Array Fold } \\
\text { Change }\end{array}$ & $\begin{array}{l}\text { Q-PCR data } \\
\text { Fold Change }\end{array}$ & P-value & $\begin{array}{l}\text { EB Array Fold } \\
\text { Change }\end{array}$ & $\begin{array}{l}\text { Q-PCR data } \\
\text { Fold Change }\end{array}$ & P-value \\
\hline \multicolumn{10}{|c|}{ Tgf-beta pathway } \\
\hline$|d|$ & $\begin{array}{l}\text { Inhibitor of DNA } \\
\text { binding I }\end{array}$ & NM 010495 & 2 & 9.2 & $8.43 \pm 2.09$ & 0.013 & 7.4 & $23.3 \pm 4.14$ & 0.0017 \\
\hline Id2 & $\begin{array}{l}\text { Inhibitor of DNA } \\
\text { binding } 2\end{array}$ & NM 010496 & 12 & 3.8 & $7.23 \pm 2.32$ & 0.1193 & 1.7 & n.d. & n.d. \\
\hline Id 3 & $\begin{array}{l}\text { Inhibitor of DNA } \\
\text { binding } 3\end{array}$ & NM 008321 & 4 & 2.8 & $3.13 \pm 0.72$ & 0.0279 & 1.8 & n.d. & n.d. \\
\hline GdfI & $\begin{array}{l}\text { Growth differentiation } \\
\text { factor I }\end{array}$ & NM 008107 & 8 & 4.0 & $3.73 \pm 0.18$ & $<0.0001$ & 1.75 & $4.01 \pm 0.56$ & 0.0018 \\
\hline Lefty2 (Ebaf) & $\begin{array}{l}\text { Left-right } \\
\text { determination factor } 2\end{array}$ & $\underline{\text { NM } 177099}$ & 1 & 3.7 & $5.47 \pm 1.18$ & 0.0096 & 1.47 & n.d. & n.d. \\
\hline LeftyI & $\begin{array}{l}\text { Left-right } \\
\text { determination factor I }\end{array}$ & NM 010094 & 1 & 1.6 & $1.77 \pm 0.1$ & 0.0004 & - & n.d. & n.d. \\
\hline Tgfb2 & $\begin{array}{l}\text { Transforming growth } \\
\text { factor, beta } 2\end{array}$ & NM 009367 & 1 & 3.0 & n.d. & n.d. & - & n.d. & n.d. \\
\hline Msx I & Homeobox, msh-like I & NM 010835 & 5 & 1.7 & n.d. & n.d. & 2.5 & n.d. & n.d. \\
\hline \multicolumn{10}{|c|}{ Extracellular matrix related } \\
\hline$M m p / 4$ & $\begin{array}{l}\text { Matrix } \\
\text { metalloproteinase 14 } \\
\text { (membrane-inserted) }\end{array}$ & NM 008608 & 14 & 4.5 & $5.44 \pm 0.57$ & 0.0002 & 3.2 & $5.16 \pm 0.85$ & 0.0028 \\
\hline Mmp9 & $\begin{array}{l}\text { Matrix } \\
\text { metalloproteinase } 9\end{array}$ & NM 013599 & 2 & 1.6 & $2.97 \pm 0.33$ & 0.001 & 1.54 & $1.79 \pm 0.28$ & $0.092^{*}$ \\
\hline Cd44 & CD44 antigen & NM 00985I & 2 & 2.7 & $7.25 \pm 2.73$ & $0.0625^{*}$ & 1.9 & $5.28 \pm 1.62$ & 0.0409 \\
\hline Tgfblil (Hic5) & $\begin{array}{l}\text { Transforming growth } \\
\text { factor beta I induced } \\
\text { transcript I }\end{array}$ & NM 009365 & 7 & 2.8 & $7.39 \pm 2.54$ & 0.046 & 2.1 & $6.26 \pm 1.95$ & 0.0357 \\
\hline
\end{tabular}

Gastrulation markers

\begin{tabular}{|c|c|c|c|c|c|c|c|c|c|}
\hline Gsc & Goosecoid homeobox & NM 010351 & 12 & - & n.d. & n.d. & 15 & $7.11 \pm 0.79$ & $<0.0001$ \\
\hline Fgf8 & $\begin{array}{l}\text { Fibroblast growth } \\
\text { factor } 8\end{array}$ & NM 010205 & 19 & 2.0 & n.d. & n.d. & 14.1 & $13.85 \pm 2.58$ & 0.0006 \\
\hline Sp5 & $\begin{array}{l}\text { Trans-acting } \\
\text { transcription factor } 5\end{array}$ & NM 022435 & 2 & 2.4 & n.d. & n.d. & 12 & n.d. & n.d. \\
\hline$T$ & Brachyury & NM 009309 & 17 & 2.3 & n.d. & n.d. & 10.6 & $60.7 \pm 8.43$ & 0.0004 \\
\hline$L h x I$ & $\begin{array}{l}\text { LIM homeobox } \\
\text { protein I }\end{array}$ & NM 008498 & 11 & - & n.d. & n.d. & 10.6 & n.d. & n.d. \\
\hline MixLI & Mixl homeobox-like I & NM 013729 & 1 & - & n.d. & n.d. & 6 & $13.98 \pm 2.93$ & 0.0046 \\
\hline EnI & Engrailed I & NM 010133 & 1 & 1.6 & n.d. & n.d. & 4.95 & n.d. & n.d. \\
\hline Wnt8a & $\begin{array}{l}\text { Wingless-related } \\
\text { MMTV integration } \\
\text { site 8A }\end{array}$ & NM 009290 & 18 & - & n.d. & n.d. & 4.4 & n.d. & n.d. \\
\hline Sox9 & $\begin{array}{l}\text { SRY-box containing } \\
\text { gene } 9\end{array}$ & NM 011448 & 11 & - & n.d. & n.d. & 3.5 & n.d. & n.d. \\
\hline Fgfl 7 & $\begin{array}{l}\text { Fibroblast growth } \\
\text { factor } 17\end{array}$ & NM 008004 & 14 & 2.5 & n.d. & n.d. & 2.4 & n.d. & n.d. \\
\hline Wnt9a & $\begin{array}{l}\text { Wingless-type MMTV } \\
\text { integration site } 9 \mathrm{~A}\end{array}$ & NM 139298 & 11 & 2.4 & n.d. & n.d. & - & n.d. & n.d. \\
\hline Eomes & Eomesodermin & NM 010136 & 9 & - & n.d. & n.d. & 2.1 & $8.03 \pm 0.67$ & $<0.0001$ \\
\hline Chrd & Chordin & NM 009893 & 16 & - & n.d. & n.d. & 1.97 & n.d. & n.d. \\
\hline Cerl & Cerberus I homolog & NM 009887 & 4 & - & n.d. & n.d. & 1.91 & n.d. & n.d. \\
\hline Foxa2 & Forkhead box A2 & NM 010446 & 2 & - & n.d. & n.d. & 1.8 & $8.98 \pm 2.55$ & 0.0216 \\
\hline Fgf5 & $\begin{array}{l}\text { Fibroblast growth } \\
\text { factor } 5\end{array}$ & NM 010203 & 5 & - & n.d. & n.d. & 2.16 & $3.16 \pm 0.14$ & $<0.0001$ \\
\hline $\lg 2$ & $\begin{array}{l}\text { Insulin-like growth } \\
\text { factor } 2\end{array}$ & NM 010514 & 7 & 3.3 & $3.9 \pm 0.72$ & 0.0078 & 1.7 & n.d. & n.d. \\
\hline
\end{tabular}

Micro-array and Q-PCR results are presented as fold change ratios relative to normalised wild-type values. The ES array results denote the average fold change of the two independent null cell lines. Genes with a 1.5 fold decrease were considered as differentially expressed. Q-PCR data is displayed as the mean \pm standard error of the mean (SEM) of mRNA expression levels relative to Hprt. Genes validated by Q-PCR are significantly differentially expressed ( $<<0.05)$, except for those indicated by an asterisk. n.d. validation not determined. A subset of differentially expressed transcripts is shown. * indicates higher than $0.05 P$ value for $Q-P C R$ validation. 


\section{Smad4 mutant ES cells display increased expression of early endoderm markers}

Smad4 loss results in increased expression of several endoderm specific markers (Table 2). For example, Dpp4 expression increased by roughly 3 -fold. Dpp4 is normally activated in the VE shortly after implantation and is undetectable in the epiblast and undifferentiated wild-type ES cells [43]. Similarly, Dab2 is expressed in the VE and is required for surface sorting and positioning of endoderm cells [44,45]. Dab2 expression was increased in Smad4 mutant ES cells. Dab2 is a downstream target of Gata6 [46], a well-characterised endoderm marker $[47,48]$. QPCR shows roughly an 8 fold-increase in Gata6 levels in one of the Smad4 null ES cell lines (Table 2). H19, an imprinted gene that is normally expressed in the endodermal lineage [49], as well as Decorin, another endoderm marker, both show increased expression (Table 2). These results suggest that signalling cues responsible for guiding early endoderm development are substantially changed in the absence of Smad4.

\section{Dramatically decreased expression of gastrulation stage markers}

Smad4 null embryos arrest at E6.5, fail to acquire initial anterior-posterior polarity and lack expression of nascent mesoderm markers. Previous studies described decreased expression of $T$ (nascent mesoderm marker) and Hnf4 (primitive endoderm marker) at early stages of EB differentiation $[17,19]$. Conditional rescue experiments demonstrate that Smad4 is non-essential for mesoderm formation and patterning, but is required for development of the anterior primitive streak (APS) and its derivatives [19]. Here we detect a dramatic down-regulation of primitive streak markers in Smad4 null EBs (Table 1). Besides $T$, we also observe down-regulated expression of the Nodal targets (Gsc and Foxa2), as well as APS markers (Gsc, Lhx1 and Foxa2).

\section{Smad4-dependent pathways regulate expression of extra- cellular matrix components}

Smad4 null ES cells and EBs also display decreased expression of several extracellular matrix (ECM) related genes (Table 1). Hic-5, also known as Tgf $\beta 1 \mathrm{i1}$, initially identified due to its TGF- $\beta$ - and hydrogen peroxide-inducible expression [50], is a homolog of the multi-domain protein paxillin. Both Hic-5 and paxillin localise to focal adhesion sites and interact with the focal adhesion kinase (FAK) [51]. These membrane sub-compartments, where integrin clusters form, link the actin cytoskeleton with the ECM and are essential to mediate intracellular signalling. FAK phosphorylates paxillin to provide additional docking sites for downstream adaptor molecules that collectively regulate cell migration. In NIH $3 \mathrm{~T} 3$ cells, Hic-5 competes with paxillin and inhibits paxillin phosphorylation [52]. Hic-5 also controls cell spreading and functions as a regulator of epithelial-to-mesenchymal transition (EMT) [52,53]. Here we observed decreased Hic-5 expression (Figure 1B) and conversely, as predicted, increased levels of phospho-paxillin in Smad4 null ES cells (Figure 1C).

\section{Smad4 loss results in defective endoderm migration during EB differentiation}

Loss of Smad4 leads to increased expression of the ECM component laminin alpha1 (Table 2). ECM proteins regulate parietal endoderm differentiation and migration in EB outgrowth assays, in a fibronectin-dependent manner [54]. To directly test possibly impaired migratory abilities of Smad4 mutant endodermal derivatives, EBs grown in suspension were plated on fibronectin and allowed to attach and spread. Outgrowth and migration of Smad4 deficient EBs was dramatically reduced compared to wildtype (Figure 3A). Morphometric analysis revealed that migration decreased by roughly 50\% (Figure 3B). Moreover, Smad4 mutant EB cultures grown in the absence of LIF for 6 days contain a substantial number of compact highly adherent cells expressing Oct4 (Figure 3C), a wellcharacterised pluripotency marker $[55,56]$. Thus, Smad4 is required to down-regulate expression of non-canonical early potency markers/transcription factors such as Zscan4, Rhox5 and Tbx3 (Table 2), while promoting the pathways responsible for endoderm formation.

\section{Smad4 functional loss causes defective ECM remodelling}

Smad4 mutant ES cells and EBs also express decreased levels of matrix-metalloproteinases (Mmps), notably Mmp14 and Mmp9 (Table 1). Mmp14 is a membrane-tethered enzyme, while Mmp9 is secreted [57]. Mmp14 is considered as a master Mmp because it promotes activation of additional Mmps [58]. Mmp-mediated degradation of the ECM allows cells to migrate and also releases biologically active ligands, including TGF- $\beta$ s, from the ECM [57]. Reduced Mmp14 expression has been described in Smad4 null neural crest derived cells [24], whereas, Mmp9 was previously identified as a Smad2/3 target gene in $\mathrm{HaCaT}$ cells [59].

The present findings that Smad4 loss results in decreased Mmp9 and Mmp14 expression suggest that endodermal migration may potentially reflect an inability to breakdown and remodel the ECM. To evaluate this possibility, next we examined EB outgrowths for expression of the basement membrane components laminin and collagen IV. As shown in Figure 4A, Smad4 mutant outgrowths display a striking increase in extracellular deposition of basement membrane components. Laminin and collagen IV expression is readily detectable in wild-type cells, but is strongly up-regulated in the absence of Smad4 (Figure $4 \&$ Additional file 3). Laminin alpha1 transcripts are also upregulated (Table 2). Increased production of ECM pro- 
Table 2: Up-regulated genes in Smad4 null ES cells andlor day 4 embryoid bodies

\begin{tabular}{|c|c|c|c|c|c|c|c|c|c|}
\hline \multicolumn{4}{|c|}{ Up-regulated } & \multicolumn{3}{|c|}{ Embryonic Stem Cell Array } & \multicolumn{3}{|c|}{ Day 4 Embryoid Body Array } \\
\hline Gene ID & Gene Description & RefSeq & Chr & $\begin{array}{l}\text { ES Array } \\
\text { Fold Change }\end{array}$ & $\begin{array}{l}\text { Q-PCR data } \\
\text { Fold Change }\end{array}$ & P-value & $\begin{array}{l}\text { EB Array Fold } \\
\text { Change }\end{array}$ & $\begin{array}{l}\text { Q-PCR data } \\
\text { Fold Change }\end{array}$ & P-value \\
\hline \multicolumn{10}{|c|}{ Early ICM or ES markers } \\
\hline Pramel7 & $\begin{array}{l}\text { Preferentially expressed } \\
\text { antigen in melanoma like } 7\end{array}$ & NM 178250 & 2 & 6.0 & $6.96 \pm 1.09$ & 0.002 & - & n.d. & n.d. \\
\hline $\begin{array}{l}\text { Calcoco2 } \\
\text { (Ndp52II) }\end{array}$ & $\begin{array}{l}\text { Calcium binding and coiled- } \\
\text { coil domain } 2\end{array}$ & $\underline{N M \quad 029755}$ & 11 & 3.0 & $2.66 \pm 0.39$ & 0.0112 & 1.45 & n.d. & n.d. \\
\hline Zscan4 & $\begin{array}{l}\text { Zinc finger and SCAN domain } \\
\text { containing } 4 \mathrm{C}\end{array}$ & NM 001013765 & 7 & 2.45 & $2.24 \pm 0.32$ & $0.0525^{*}$ & 2.1 & $2.94 \pm 0.26$ & 0.0002 \\
\hline Magea8 & Melanoma antigen, family A, 8 & NM 020020 & $x$ & 2.325 & $10.7 \pm 0.21$ & $<0.0001$ & - & n.d. & n.d. \\
\hline Tbx3 & T-box 3 & NM 011535 & 5 & 3.0 & $2.06 \pm 0.48$ & $0.1673^{*}$ & 2.6 & $3.78 \pm 1.08$ & $0.0544 *$ \\
\hline Pramel4 & $\begin{array}{l}\text { Preferentially expressed } \\
\text { antigen in melanoma like } 4\end{array}$ & NM_001001319 & 4 & 2.0 & $5.26 \pm 0.58$ & 0.0212 & 1.5 & n.d. & n.d. \\
\hline \multicolumn{10}{|c|}{ Germ cell markers } \\
\hline Tuba3a & Tubulin, alpha 3A & NM 009446 & 6 & 4.8 & $5.76 \pm 0.74$ & 0.0013 & 4.1 & $5.46 \pm 0.87$ & 0.0024 \\
\hline Dnmt3l & $\begin{array}{l}\text { DNA (cytosine-5-)- } \\
\text { methyltransferase 3-like }\end{array}$ & NM 019448 & 10 & - & n.d. & n.d. & 3.7 & $4.43 \pm 0.73$ & 0.0038 \\
\hline $\begin{array}{l}\text { Smclb } \\
(\text { Smcl12) }\end{array}$ & $\begin{array}{l}\text { Structural maintenance of } \\
\text { chromosome } \mathrm{Ib}\end{array}$ & NM 080470 & 15 & 5.7 & n.d. & n.d. & 2.8 & n.d. & n.d. \\
\hline Dazl & Deleted in azoospermia-like & NM 010021 & 17 & 3.1 & n.d. & n.d. & 1.5 & n.d. & n.d. \\
\hline Aire & Autoimmune regulator & NM 009646 & 10 & 2.8 & $5.11 \pm 0.91$ & 0.0056 & 4.1 & $5.03 \pm 1.15$ & 0.0139 \\
\hline Wdr20b & WD repeat domain $20 \mathrm{~b}$ & NM_027614 & 12 & 2.6 & n.d. & n.d. & 1.45 & n.d. & n.d. \\
\hline \multicolumn{10}{|c|}{ Endoderm markers } \\
\hline Dpp4 & Dipeptidylpeptidase 4 & NM 010074 & 2 & 2.8 & n.d. & n.d. & 3.8 & $2.52 \pm 0.35$ & 0.0111 \\
\hline $\mathrm{HI9}$ & HI9 fetal liver mRNA & NR 001592 & 7 & 2.1 & $1.58 \pm 0.08$ & 0.0049 & 2.7 & $3.81 \pm 0.09$ & $<0.0001$ \\
\hline Dab2 & Disabled homolog 2 & NM 023118 & 15 & 1.8 & n.d. & n.d. & - & n.d. & n.d. \\
\hline Den & Decorin & NM 007833 & 10 & 1.6 & $2.4 \pm 0.27$ & 0.0055 & 1.8 & $1.98 \pm 0.56$ & $0.1521 *$ \\
\hline Lamal & Laminin, alpha I & NM 008480 & 17 & - & n.d. & n.d. & 3.9 & n.d. & n.d. \\
\hline Hnf4a & $\begin{array}{l}\text { Hepatic nuclear factor } 4 \text {, } \\
\text { alpha }\end{array}$ & NM 008261 & 2 & - & n.d. & n.d. & 1.48 & n.d. & n.d. \\
\hline Gata6 & GATA binding protein 6 & NM 010258 & 18 & 4.0 & $8.18 \pm 1.71$ & 0.0005 & - & n.d. & n.d. \\
\hline
\end{tabular}

Micro-array and Q-PCR results are presented as fold change ratios relative to normalised wild-type values. The ES array results denote the average fold change of the two independent null cell lines. Genes with a I.5 fold decrease were considered as differentially expressed. Q-PCR data is displayed as the mean \pm SEM of mRNA expression levels relative to Hprt. Genes validated by Q-PCR are significantly differentially expressed $(p<0.05)$, except for those indicated by an asterisk. Q-PCR validation for Gata6, indicated in bold, was performed using only the FNN Smad4 null ES cell line. A subset of up-regulated genes transcripts is shown. * indicates higher than $0.05 \mathrm{P}$ value for QPCR validation.

teins, in combination with reduced levels of ECM degrading enzymes, thus results in enhanced deposition of basement membrane components and decreased migration across the fibronectin substrate. Similarly, increased levels of laminin and collagen IV expression and hence an enlarged basement membrane underlying the outer layer of primitive endoderm was detected in Smad4 mutant EBs (Figure 4B \& Figure 5). Additionally, the outer endoderm layer was thicker and strongly positive for Dab2 and the mutant EBs were smaller than the WT controls overall (Figure 5). Thus the differences initially detectable in early day 4 EBs continued throughout the differentiation process (Figure 4B \& Figure 5). The excess production of laminin alpha1 in combination with reduced expression of the ECM degrading enzymes Mmp14 and Mmp9 (Table 1) disrupts migration and signalling by the Smad4 mutant endoderm.

\section{Smad4 mutant embryos contain an excessive embryonic basement membrane}

To examine whether similar changes contribute to the mutant phenotype in vivo, we analysed Smad4 null embryos. As expected, the VE is distinctly thicker and the epiblast is significantly reduced in embryos lacking Smad4 (Figure 6) [17-19]. Previously published H\&E sections clearly show a thickened single endoderm layer [19]. Interestingly as shown in Figure 6A we observe a marked increase in collagen IV staining between the epiblast and visceral endoderm layer. As shown above, mutant endodermal cell populations display increased deposition of basement membrane that probably leads to a complete block of reciprocal signalling between the extra-embryonic endoderm and epiblast. 
A.
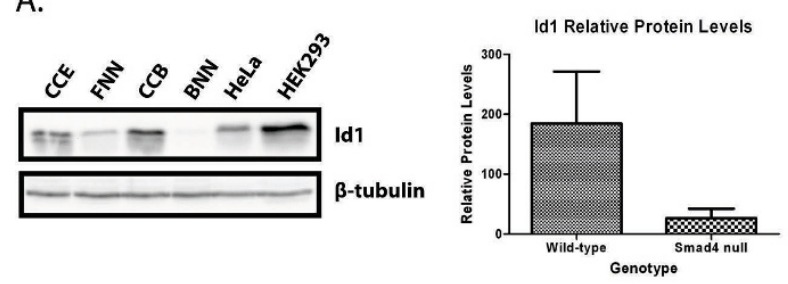

B.

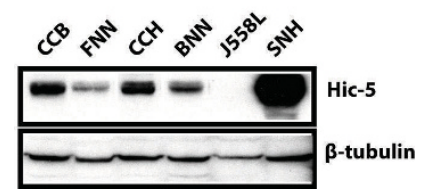

C.

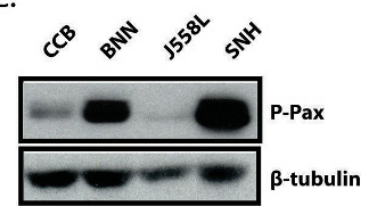

Figure I

Western blot analysis of candidate genes mis-regulated in Smad4 null ES cells. A. Id I expression levels are 7-fold lower in Smad4 null (FNN/BNN) cell lysates in comparison with wild-type (CCE/CCB) ES cells. Id I protein levels were normalised to $\beta$-tubulin expression. HeLa, a human epithelial adenocarcinoma cell line, and the human embryonic kidney line, HEK293, were used as positive controls. B. Hic-5 protein levels are reduced in Smad4 null (FNN/BNN) in comparison with wild-type (CCB/CCH) ES cell lysates. $\mathbf{C}$. Elevated phospho-Paxillin expression by Smad4 deficient ES cells. J558L, a myeloma cell line and embryonic fibroblasts, $\mathrm{SNH}$, were used as negative and positive controls, respectively.

\section{Discussion}

Mis-regulated genes identified here in Smad4 mutant ES cells and those previously characterised in screens analysing Smad4 targets in tumour cell lines show surprisingly little overlap [32,60,61]. Besides technical issues, such as the use of different array platforms, this difference probably also reflects cell type specific gene expression patterns. We employed Smad4 genetically null cells, whereas previous studies analysed the consequences of knock-down of Smad4 using RNAi or profiled tumour cell lines, in all likelihood carrying multiple mutations that could potentially complicate the analysis. Smad4 is broadly expressed in embryonic and adult tissues. Nonetheless, cellular responses activated by TGF- $\beta /$ Nodal/BMP signalling pathways are remarkably diverse. Thus it seems likely that Smad4-dependent targets will be influenced by cell-type specific partnerships and are highly context dependent.

Previous studies demonstrate that growth characteristics of Smad4 null ES cells are indistinguishable from wildtype $[17,62]$. As judged by Smad2 phosphorylation, TGF$\beta /$ Nodal signalling is constitutively active in undifferentiated ES cells ([63] \& this study), but its role in promoting ES cell self-renewal remains unclear $[63,64]$. BMP signalling activates the Id family of target genes and is required to sustain self-renewal and pluripotency of ES cells [25].
A.

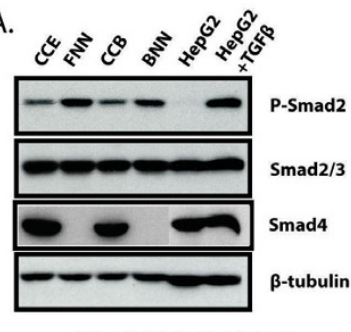

P.Smad2 Relative Protein Lovel

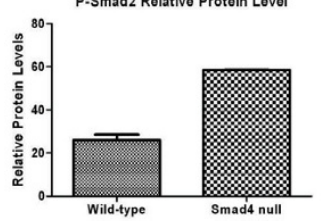

B.

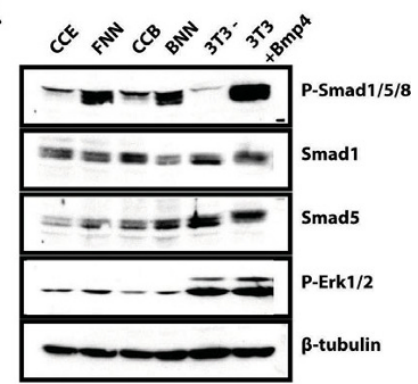

Figure 2

Loss of Smad4 expression results in increased phosphorylation of R-Smads. A. Western blots of lysates from wild-type (CCE \& CCB) and Smad4 null ES cells (FNN \&

$B N N$ ) were probed with antibodies directed against $R-S m a d s$ Smad2/3 or phospho-Smad2. $\beta$-tubulin acts as a loading control. Steady-state levels of Smad2/3 are unperturbed but PSmad2 expression is strongly upregulated in Smad4 null ES cells. TGF- $\beta$ stimulated HepG2 cells were included as a positive control. B. Similarly P-SmadI/5/8 levels are markedly enhanced in Smad4 null ES cells, wheras steady state levels of SmadI and Smad5 are unaffected. Bmp4 treated NIH3T3 cells were included as a positive control. As judged by unchanged P-ErkI/2 levels loss of Smad4 function has no detectable effect on Erk signalling.

Smad4 nucleocytoplasmic shuttling is not required for RSmad phosphorylation or nuclear localisation [65]. RSmad dephosphorylation and nuclear export is thought to be required for optimal TGF- $\beta$ signalling $[66,67]$. Here we demonstrate that Smad4 loss leads to increased steady state levels of both BMP and TGF- $\beta$ phosphorylated RSmads (Figure 7). Enhanced R-Smad phosphorylation levels potentially reflect decreased dephosphorylation and/or nuclear export $[66,67]$. In the absence of Smad4, R-Smads may be less efficiently recognised by C-terminal phosphatases and/or actively retained in the nucleus.

Another possibility is that increased levels of phosphorylated R-Smads may be caused by reduced expression of Nodal antagonists, namely Lefty 1 and Lefty $2[27,28]$. The lack of negative feedback regulation may dramatically shift gene expression patterns. Smad4 conditional deletion in cardiomyocytes results in increased phosphorylation of Erk1/2 [68] and activation of the MAPK pathway probably contributes to defective heart development. Erk1/2 signalling has also been implicated in controlling the transition of ES cells from self-renewal to differentiation [69]. Here, we observe loss of Smad4 in ES cells has no effect on phospho-Erk1/2 activity. Increased R-Smad 

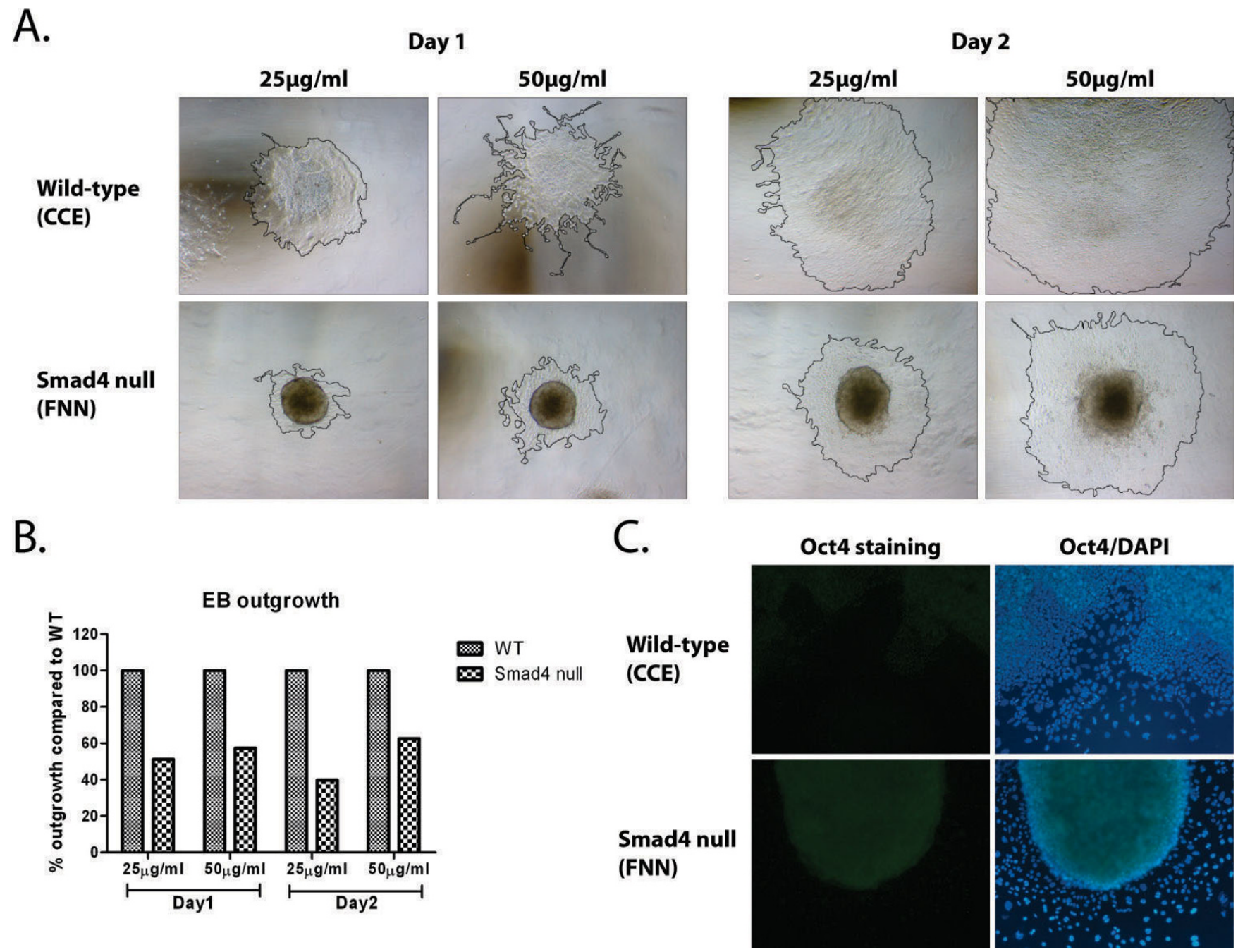

Figure 3

Smad4 null embryoid bodies display defects in endoderm migration. A. Day 4 wild-type and Smad4 null EBs were plated onto fibronectin-coated dishes and cultured for 2 days. At both fibronectin concentrations, outgrowth and migration were markedly reduced in Smad4 mutant EBs. B. The surface area of the outgrowths was compared using ImageJ. Smad4 null EB outgrowths, plotted as a percentage of the corresponding wild-type, show a reduction in the total surface area of outgrowth. C. Oct4 staining of EBs grown on $25 \mu \mathrm{g} / \mathrm{ml}$ fibronectin for 2 days. In contrast to barely detectable Oct4 levels in wildtype EB derivatives Smad4 null EBs retain robust expression.

phosphorylation in the absence of enhanced MAPK signalling may also contribute to the changes in transcriptional profiles.

As expected Smad4 mutant ES cells and EBs display dramatically reduced levels of nascent mesoderm markers (e.g. T, Mixl1, Gsc). Additionally, loss of Smad4-dependent signals results in increased expression of non-canonical stem cell genes, including Pramel7, Zscan4 and Tbx3. The precise roles played by these potency genes, (notably Calcoco2, Pramel4, Zscan4), remains ill defined. Pramel4, Pramel7 and Calcoco2 were initially identified as Oct-4 related genes [70]. Pramel7 is normally expressed in the compacted morula and the inner cell mass (ICM) of the early blastocyst and Pramel7 over-expression results in LIF-independent self-renewal [33].

Only one ZSCAN4 gene has been identified in humans, while nine paralogous Zscan4 genes are present in the mouse genome [37]. Of these, six are known to be expressed and three of these, namely Zscan4c, Zscan $4 d$ and Zscan4f, encode highly similar proteins [37]. Zscan $4 d$ is an abundant transcript at the 2-cell stage but its expression is rapidly turned off. Expression of Zscan4c, and to a lesser extent Zscan4f, is up-regulated in blastocyst outgrowths and is detectable in a mosaic fashion in ES cultures [37]. 
A.

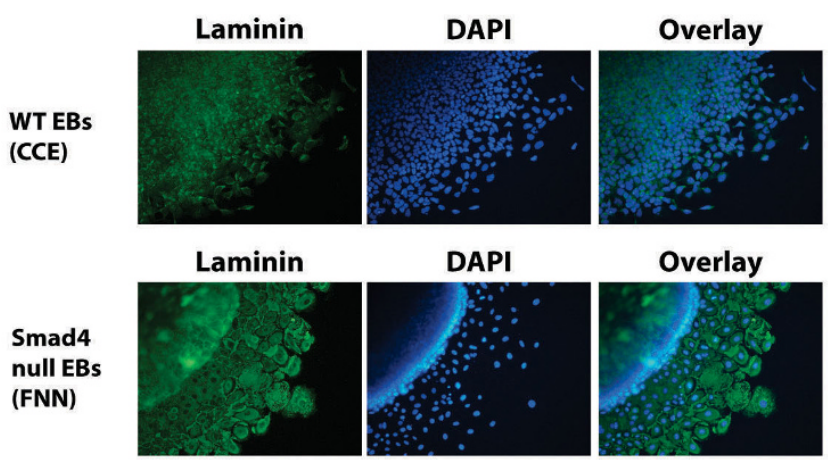

B.

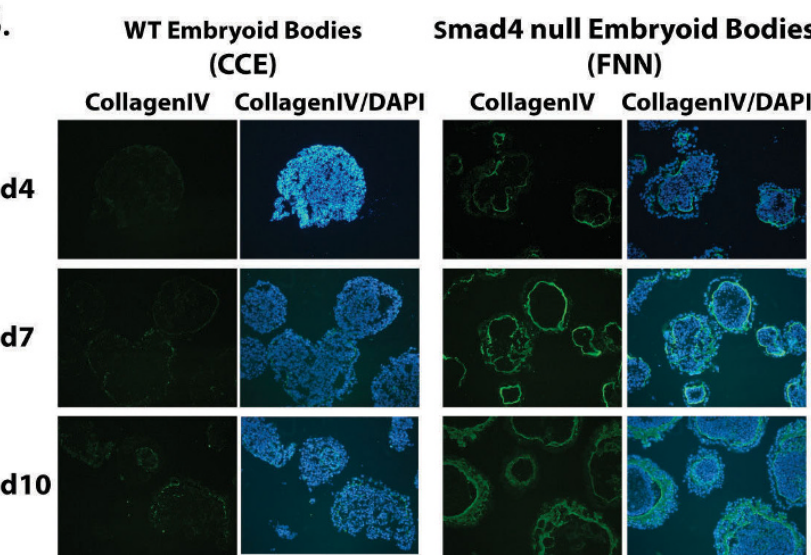

Figure 4

Increased expression of basement membrane proteins by Smad 4 mutant EB outgrowths. A. Day 4 wildtype and Smad4 null EBs grown for 2 days on fibronectincoated $(25 \mu \mathrm{g} / \mathrm{ml})$ dishes. Smad4 mutant EBs express increased levels of laminin. B. Cryosections of day 4, day 7 and day 10 suspension EBs stained for collagen IV. Smad4 mutant EBs display progressively increased basement membrane deposition beneath the outer endoderm layer.

RNAi knock-down experiments demonstrate that Zscan4 is essential for pre-implantation development [37].

$T b x 3$ is also required for ES cell proliferation. Enforced expression results in LIF-independent self-renewal and is sufficient to repress mesodermal commitment [36]. Similarly, Rhox 5 over-expression maintains ES cell self-renewal in the absence of LIF [33] and inhibits EB differentiation [40]. Rhox5 is also expressed in the primitive endoderm but its role in vivo remains unknown. Interestingly, expression of the autoimmune regulator Aire is also up-regulated in Smad4 mutant cells. Aire is normally expressed in medullary thymic epithelial cells (MTECs) and in the testis $[71,72]$. Aire expression by MTECs induces expression of Nanog, Oct4, and Sox2, and is required for promiscuous

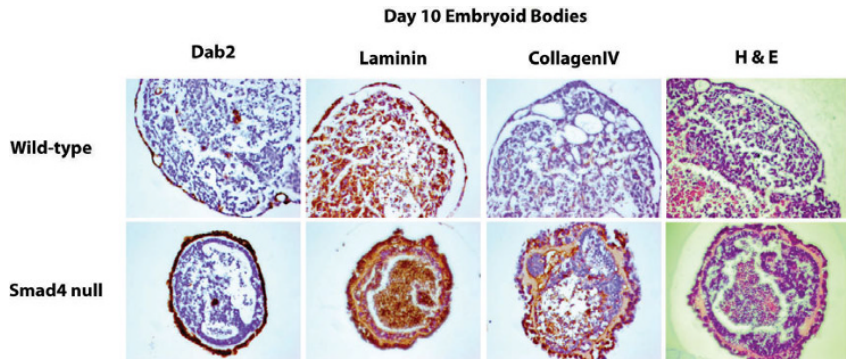

Figure 5

Mature Smad4 mutant embryoid bodies display a thickened endoderm and expanded basement membrane. The day 10 Smad4 null EBs strongly express Dab2.

The thick extracellular matrix, detectable by hematoxylin and eosin (H\&E) staining, stains positive for both laminin and collagenIV.

expression of tissue-restricted antigens [71,73]. These activities are required for imposing central tolerance and controlling autoimmunity. Increased Aire expression may similarly contribute to promiscuous gene expression patterns described here in Smad4 mutant ES cells.

Smad4 mutant ES cells also up-regulate expression of Dab2, Rhox5 and Hnf4a, which are normally expressed in the early primitive endoderm [74]. The relatively immature Smad4 mutant endoderm cells may fail to progress towards a more differentiated VE state. Consistent with this idea, the endoderm formed by mutant EBs displays a distinctive more rounded thicker morphology, similar to that present in mutant embryos. Additionally, marker genes normally present in mature VE such as Fgf8, Foxa2, Cer1, Gsc and Lhx1 are markedly down-regulated. Another possibility is that these genes are under-represented due to the block in A-P patterning and/or the failure to induce mesodermal and definitive endoderm cell lineages. These observations reinforce the idea that Smad4-dependent signals are essential in the early primitive endoderm to promote reciprocal signalling and pattern the underlying epiblast.

During mouse embryogenesis, the primitive endoderm generates a layer of BM between the VE and the epiblast (embryonic BM), while the highly secretory parietal endoderm (PE) cell population, in conjunction with the trophectoderm, is responsible for producing Reichert's membrane, the protective layer between the embryo and the maternal uterine environment. The BM overlying the embryo polarises the epiblast and stimulates cavitation [75]. Numerous mutations that disrupt basement membrane synthesis cause early post-implantation lethality [76-78]. Mmps play important roles in ECM remodelling, however their functional contributions to early embryonic development remains ill defined. It has been pro- 


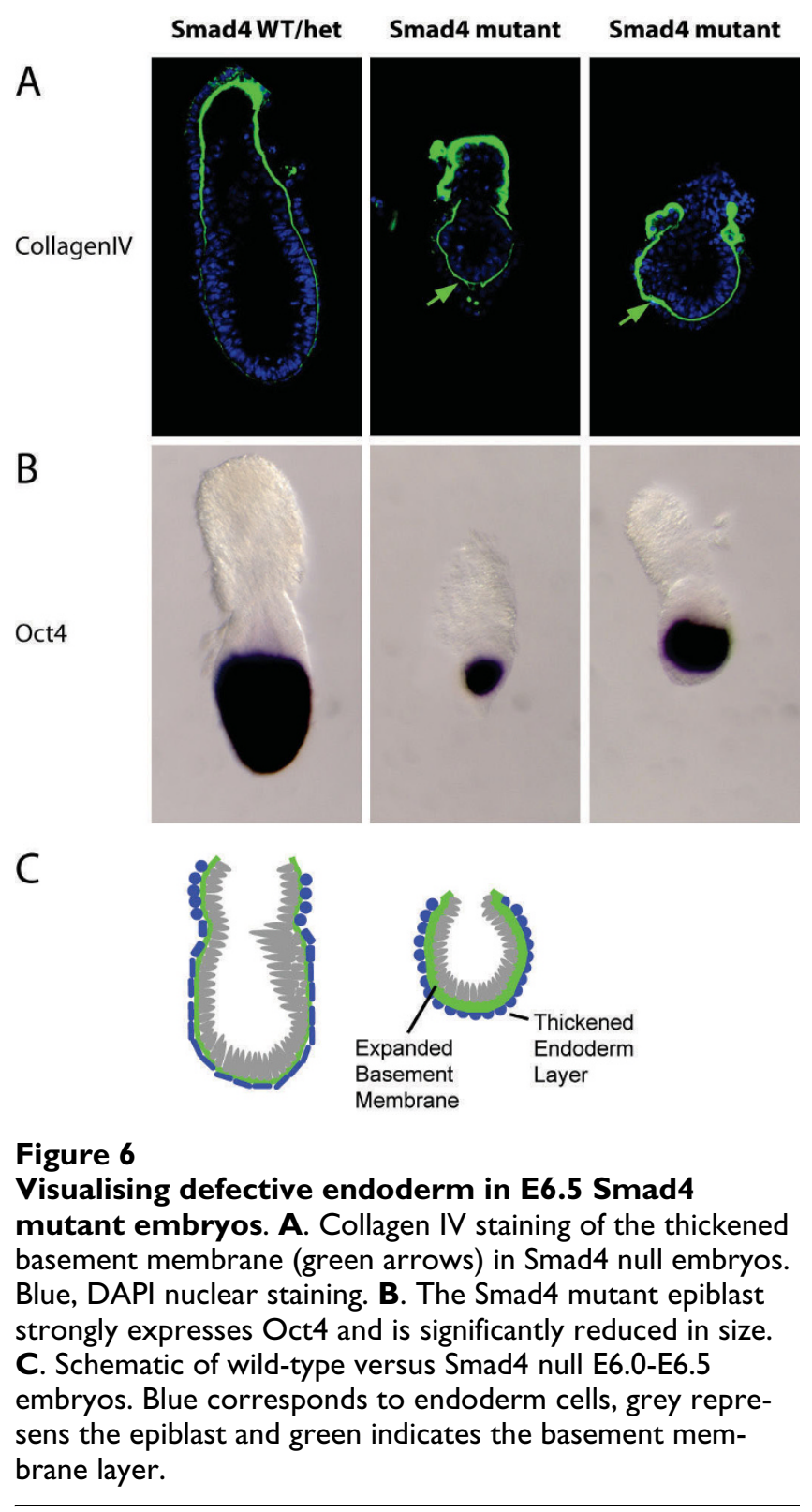

posed that Mmps synthesised by the trophectoderm promote implantation of the embryo into the uterine wall [79]. Mmp9 and Mmp2 are known to be expressed by ICM outgrowths and cultured PE-like cells [80,81]. However, none of the Mmp loss of function mutations generated todate disrupt early development. In all likelihood the failure to observe embryonic phenotypes simply reflects the extensive overlapping expression patterns and functional redundancy among close family members $[57,82]$.

Numerous ECM-related genes, including PAI-1, fibronectin and pro-collagens, are controlled by Smad4-independent signals $[32,62]$. The present experiments demonstrate for the first time that remodelling ECM components in the early embryo requires Smad4-dependent signals (Figure 7). Besides breaking down the ECM, Mmps can also release cell surface associated growth factors from the ECM. In particular, Mmp2 and Mmp9 release biologically active TGF- $\beta$ [83]. Cd44 and TGF- $\beta$ are known Mmp substrates $[83,84]$ and intriguingly both $C d 44$ and Tgf- 2 are mis-regulated in Smad4 mutant ES cells.

Reduced Mmp14 and Mmp9 expression in combination with up-regulated laminin production, leads to excessive $\mathrm{BM}$ deposition and results in endoderm migration defects in EB outgrowth assays. Interestingly, previous studies demonstrate that endodermal derivatives of ES cells, with a constitutively active Akt/PKB pathway, similarly produce excess $\mathrm{BM}$ underlying the endoderm layer, due to a massive increase in laminin-1 and collagen IV synthesis [85]. We speculate that cross-talk between TGF- $\beta$ and Akt/ $\mathrm{PKB}$ signalling pathways may cooperatively regulate expression and remodelling of ECM components in the early embryo.

The present results demonstrate that Smad4 mutant endodermal derivatives display defective migration in EB outgrowth assays. Similarly, Smad 4 regulates TGF- $\beta$ induced cell migration in keratinocytes and pancreatic tumour cells [32]. The epithelial-mesenchymal transitions essential in the early embryo and those associated with tumour progression exhibit striking similarities. Surprisingly little is known about TGF- $\beta /$ Smad signals required for guiding endodermal cell migration at early stages of development. Smad4 null blastocysts display defective outgrowth [18] but cell migration and proliferative capabilities are tightly coupled, making it difficult to distinguish whether Smad4 loss results in migration defects per se or can be explained due to decreased cell proliferation. Results of the EB outgrowth assays presented here clearly demonstrate that Smad4 regulates endoderm migratory capabilities in vitro. However, formation of the parietal endoderm is not impaired in Smad4 mutant embryos. Thus synthesis of Reichert's membrane forms normally despite the small size of the embryo [18]. Rather, loss of Smad function selectively disrupts VE development, probably due to impaired reciprocal signalling between the VE and the epiblast. Nodal signalling from the epiblast induces the AVE in the overlying endoderm via a Smad2 dependent pathway [5]. In turn, activation of key targets in the AVE including Foxa2, Lhx1, Cer1 and Lefty1 provide important signalling cues for patterning the epiblast (reviewed by [4]). The present experiments demonstrate that Smad4 mutant EBs show reduced expression of Cer1, a negative regulator of TGF- $\beta$ /BMP signalling, as well as Foxa 2 and Lhx1 (Table 1). Excess basement membrane produced by Smad4 mutant endoderm likely acts as a reservoir trap for 

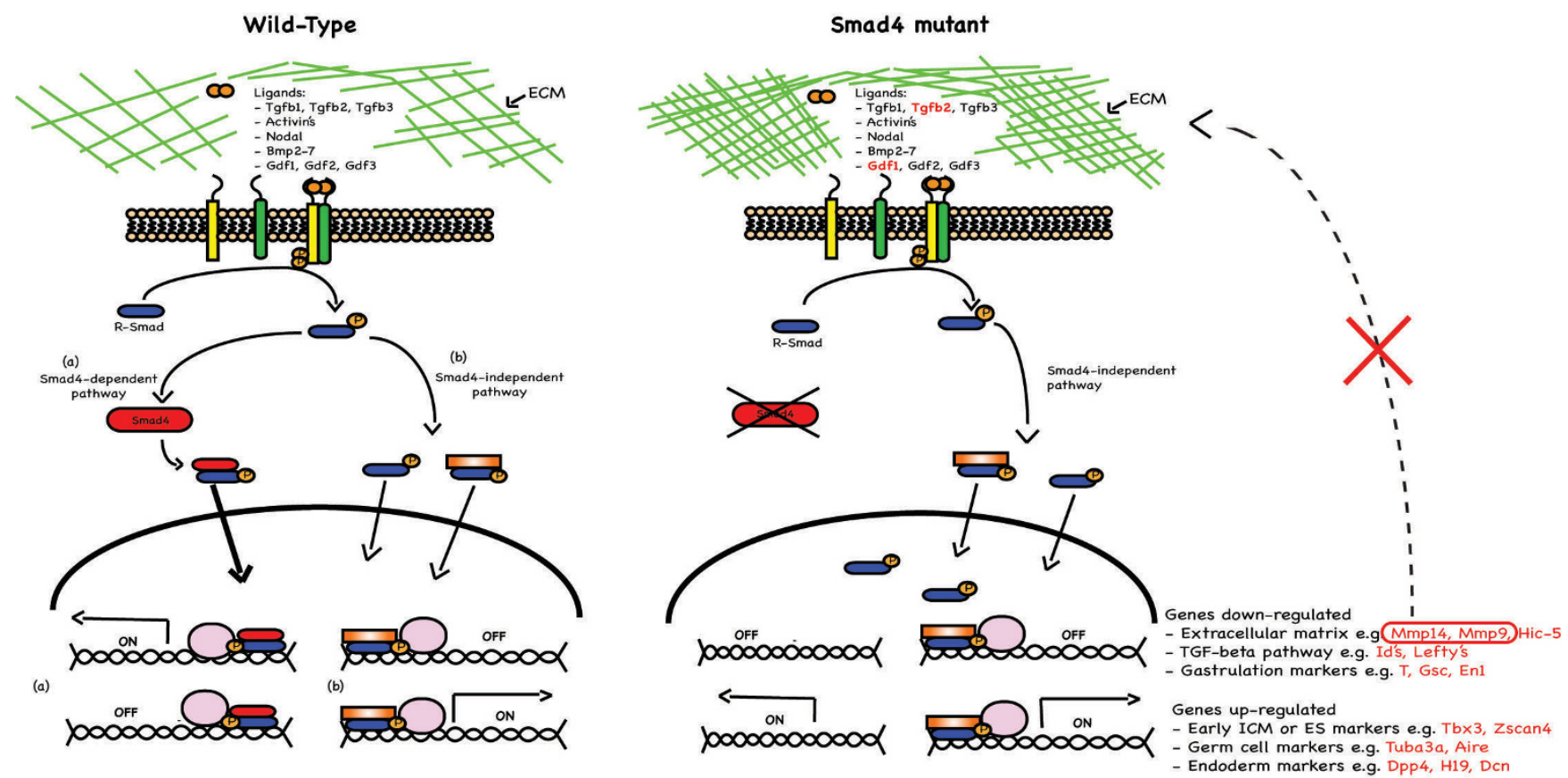

Figure 7

Smad4 controls transcriptional progammes in the early embryo. Loss of Smad4 is associated with increased levels of

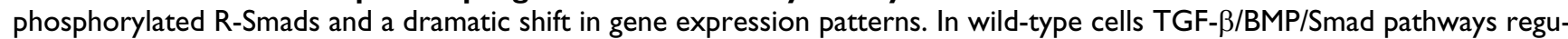
late target gene expression via (a) Smad4-dependent or (b) Smad4-independent mechanisms. In the absence of Smad4, phosphorylated R-Smads are efficiently translocated to the nucleus on their own or by interacting with another partner (indicated as an orange box). The pink circles indicate transcriptional partners required for activation or repression of genes. Mis-regulated genes in Smad4 mutant cells potentially reflect the loss of Smad4-dependent pathways or could also be due to increased Smad4-independent signalling. In Smad4 mutant cells, genes in red are mis-regulated resulting in defective endoderm differentiation and massive deposition of BM components (indicated by green mesh). In Drosophila, components of the BM, namely Collagen IV, are known to modulate BMP signalling in the extracellular space during development [89]. Overall the present results demonstrate TGF- $\beta / B M P / S m a d$ signals control expression of the extracellular matrix and reciprocally, BM components fine tune Smad signalling.

biologically active ligands and causes defective cell-cell communication between the epiblast, visceral endoderm and extra-embryonic ectoderm.

\section{Conclusion}

Our transcriptional profiling experiments have identified numerous genes that are differentially expressed in Smad4 mutant ES cells and EBs. Analysis of the gene list provides new insights into the tissue defects in Smad4 mutant embryos. The failure to down-regulate the non-canonical potency markers causes defective endodermal cell lineage commitment. Developmental arrest is associated with excess basement membrane, resulting from increased production of the ECM components and decreased expression of Mmps required for remodelling (Figure 7). The thickened BM disrupts reciprocal signalling between the VE and epiblast. Hence, deregulated expression of Smad4 target genes in the primitive endoderm results in the inability to form mesoderm and definitive endoderm.

\section{Methods \\ RNA analysis}

Wild-type (CCE \& CCB) and Smad4 null (FNN \& BNN) 129 S9/SvEvH embryonic stem cell lines adapted to grow under feeder independent conditions were routinely expanded on gelatin coated tissue culture dishes in DMEM plus 15\% FCS with 1000 units/ml recombinant LIF (Millipore). Embryoid bodies generated as described [86] were harvested at day 4 of differentiation. For RNA isolation, ES cells were seeded at $1 \times 10^{6}$ cells per $6 \mathrm{~cm}$ dish and harvested the next day at $70-80 \%$ confluency. EBs were harvested by centrifugation. Lysates prepared in RLT buffer (Qiagen) were removed by scraping and applied to a QIAshredder (Qiagen). RNA from both ES cells and EBs was isolated using an RNeasy kit (Qiagen) accordingly to the manufacturer's instructions.

\section{Array}

The ES cell Array data was generated in two phases. Intially two sets of three technical replicates from wild- 
type CCE and Smad4 null FNN ES cell lines were collected one passage apart. In the second phase three independent technical replicates collected from wild-type CCB and Smad4 null BNN ES cell lines. Each dataset was analysed in an identical manner. The EB array was performed in one phase using two technical replicates of each of all of the above four cell lines. The Illumina WG- 6 Mouse v1 Sentrix BeadArray contains 46,630 unique probe sequences targetting 34,784 unique RefSeq accession identifiers and 33,720 gene symbols. Samples were arranged randomly with respect to the 6 array positions within each BeadArray. Arrays were scanned according to manufacturer's instructions and raw intensity data extracted for each probe type using the software BeadStudio version 3.0.14. Raw signals were subtracted for background intensities and imported into R statistical scripting environment http://www.cran.r-project.org. Data was transformed using a variance stabilisation algorithm as implement in the BioConductor http://bioconductor.org package, vsn [87] and quantile normalised. Unsupervised analysis consisted of hierarchical clustering using euclidean distance and complete linkage. Differentially expressed probes were identified using the bioconductor package limma using a univariate linear model containing a genotype effect. For phase 1 an additional covariate was added for passage groups. P values were adjusted for multiple testing using the Benjamini-Hochberg false discovery rate. Probes were considered differentially expressed relative to genotype if they meet a $\mathrm{P}<0.01$ significance after adjustment for multiple testing.

Probe identifiers were fully annotated using the Mouse6_v1_1_11234304_A array manifest. Gene ontology enrichment analysis was performed using the online DAVID bioinformatics resources http:// david.abcc.ncifcrf.gov which uses a modified Fisher Exact test to ascertain whether certain gene functions are enriched in a specific gene list above what would be expected through random sampling of the array. The background frequencies of gene ontology terms were generated using all identifiers represented on the Illumina array.

\section{Q-PCR Validation}

Array data was validated by quantitative PCR analysis using a Corbett Rotagene 3000. cDNA was generated using the Superscript III Kit (Invitrogen) with oligo-dT primers. One tenth of the product was amplified in a 15 $\mu$ l SYBRGreen PCR reaction (Qiagen). Cycling conditions incorporated an initial denaturation step of $15 \mathrm{~min}$ at $94^{\circ} \mathrm{C} ; 2 \times\left(30 \mathrm{~s}\right.$ at $94^{\circ} \mathrm{C}, 1 \mathrm{~min}$ at $72^{\circ} \mathrm{C}$ and $1 \mathrm{~min} 30 \mathrm{~s}$ at $\left.72^{\circ} \mathrm{C}\right) ; 2 \times\left(30 \mathrm{~s}\right.$ at $94^{\circ} \mathrm{C}, 1 \mathrm{~min}$ at $70^{\circ} \mathrm{C}$ and $1 \mathrm{~min} 30 \mathrm{~s}$ at $\left.72^{\circ} \mathrm{C}\right) ; 30 \times\left(30 \mathrm{~s}\right.$ at $94^{\circ} \mathrm{C}, 1 \mathrm{~min}$ at $55-62^{\circ} \mathrm{C}$ and $1 \mathrm{~min}$ $30 \mathrm{~s}$ at $72^{\circ} \mathrm{C}$ ) followed by a final extension cycle of $5 \mathrm{~min}$ at $72^{\circ} \mathrm{C}$. Primer sequences and annealing temperatures are provided in Additional File 4. Quantification of foldchanges initially compared both biological replicates and was further validated using additional technical replicates. Relative gene expression was deduced using the $\Delta \Delta \mathrm{Ct}$ method [21] in comparison with Hprt as the reference. Ct values of each qPCR reaction were normalised with the respective Ct values of the Hprt. The fold change was calculated using the formula: Fold change $=2$-( $\Delta$ Ctgene1$\Delta$ Ctgene2). The resulting fold change is expressed as mean \pm SEM. Statistical analysis was performed using the Prism5 statistic package and the Students T-test.

\section{Western blot analysis}

Cell lysates prepared from Smad4+/+ (CCE, CCB) and Smad4N/N (FNN, BNN) ES cell lines using RIPA buffer were subjected to SDS-PAGE and transferred onto PVDF membranes. Membranes were blocked with 5\% milk in TBS- $T$ then incubated in primary antibodies overnight including rabbit anti-phospho-Smad2 (Cell Signalling $3101 \mathrm{~L} ; 1: 1000)$, mouse anti-Smad2/3 (Transduction 610843; 1:500), rabbit anti- $\beta$-tubulin (Santa Cruz sc9104; 1:1000), rabbit anti-Id1 (Santa Cruz sc-488; 1:500), rabbit anti-phospho-Smad1/5/8 (Upstate AB3848; $1: 1,000)$. Mouse anti-Smad1 (Santa Cruz sc-7965; 1:200), goat anti-Smad5 (Santa Cruz sc-7443; 1:200), rabbit antiphospho p44/42 MAP kinase (Erk) (Cell Signalling 9101; $1: 1000)$, rabbit anti-phospho-paxillin (Tyr 118) (Cell Signaling 2541; 1:1,000), mouse anti-Hic5 (BD Transduction $611164 ; 1: 250)$. Secondary antibodies were donkey anti-rabbit HRP (Amersham NA934V; 1:2000) and sheep anti-mouse-HRP (Amersham NA931V; 1:2000). Blots were developed by chemiluminescence using ECL plus (Amersham) and quantified using a Bio-Rad GelDoc and the Quantity one software.

\section{Embryoid body outgrowth and migration assays}

Wild-type and Smad4 null d4 EBs were plated in Lab-Tek chamber glass slides (Nunc) previously coated 25-50 $\mu \mathrm{g} /$ ml with fibronectin (Sigma), cultured for 2 days, rinsed with PBS, fixed with 4\% paraformaldehyde, washed in PBS and then permeabilized with $0.3 \%$ Triton X-100-PBS and blocked in 10\% FCS, $0.3 \%$ BSA, $0.3 \%$ Triton X-100 in PBS for $30 \mathrm{~min}$ at room temperature. Slides were then incubated with primary antibodies as follows, anti-laminin (Sigma, L-9393; 1:200); anti-collagenIV (Chemicon, AB756P; 1:100) anti-Oct4 (Santa Cruz sc-8628; 1:200). Slides were incubated with either a goat anti-rabbit IgG or donkey anti-goat IgG secondary antibody (Alexa Fluor488, Molecular Probes; 1in 500) and mounted with Vectashield mountant containing the nuclear counterstain 4',6-diamidino-2-phenylindole (DAPI) (Vector Labs H-1200). Fluorescent images were captured with a Zeiss epifluorescence microscope. Morphometric analysis was carried out using the ImageJ program. 


\section{Cryo-sectioning, immunocytochemistry and immunohistochemistry}

EBs were washed with PBS, fixed in 4\% paraformaldehyde for 30 minutes at room temperature (RT), washed in PBS, transferred into $7.5 \%$ sucrose in PBS for $3 \mathrm{hrs}$ at RT and then immersed in $15 \%$ sucrose in PBS overnight at $4^{\circ} \mathrm{C}$. The sucrose solution was removed, replaced with TissueTek O.C.T. compound and samples transferred into a cryo mould and frozen in an iso-pentane bath on dry ice. $7 \mu \mathrm{m}$ cryosections were collected onto gelatin coated positively charged Superfrost glass slides and were stained with primary antibodies: anti-laminin (Sigma, L-9393; 1:200); anti-collagenIV (Chemicon, AB756P; 1:100) followed by goat anti-abbit IgG $\mathrm{H}+\mathrm{L}$ secondary antibody (Alexa Fluor488, Molecular Probes; 1:500) and mounted with Vectashield mountant containing DAPI. Images were acquired using an epifluorescence microscope (Carl Zeiss). For immunohistochemistry, EBs were fixed in $4 \%$ paraformaldehyde, dehydrated and embedded in paraffin wax using standard methods. Dewaxed sections were processed for antigen retrieval by boiling for $20 \mathrm{~min}$ in Dako antigen retrieval solution and washed in PBS-T $(0.02 \%)$ for $10 \mathrm{~min}$. Slides were blocked with either 5\% skimmed milk or $5 \%$ goat serum for 1 hour, then incubated with primary antibody overnight at $4^{\circ} \mathrm{C}$ at $1: 400$ dilution. Antibodies included anti-laminin, anti-collagenIV (as before) and anti-Dab2 (BD Transduction 610464). Sections were washed three times in PBS-T for 5 min. Blocking of endogenous peroxidase, incubation with peroxidase-labelled polymer and detection with $\mathrm{DAB}+$ chromagen were performed according to the manufacturer's instructions (DAKO kit). Sections were counterstained with haematoxylin using standard methods.

\section{Basement membrane staining and whole-mount in situ hybridisation analysis of embryos}

E6.5 embryos were fixed in 4\% PFA/PBS, washed in $0.1 \%$ TritonX/PBS and permeabilised in $0.5 \%$ TritonX/PBS. Following three washes in $0.1 \%$ TritonX/PBS, embryos were blocked in 5\% FBS, $0.2 \%$ BSA, $0.1 \%$ TritonX - PBS and incubated overnight in primary rabbit polyclonal antiCollagen IV (Chemicon AB756; 1:100). Embryos were washed extensively with $0.1 \%$ TritonX/PBS and then incubated in anti-rabbit Alexa-Fluor 488 secondary antibody (Invitrogen A11034; 1:200). Embryos were further washed extensively with $0.1 \%$ TritonX/PBS, immersed in Vectashield mounting media containing DAPI and imaged using laser scanning confocal microscopy (Zeiss LSM 710 confocal microscope). Whole mount in situ hybridisation was performed according to standard procedures [88] using a probe for Oct4 [5]. The experimental protocols described in this report have been approved by the Ethical Review Committee of the University of Oxford.

\section{Authors' contributions}

IC carried out Q-PCR, Western blot analysis and microscopy experiments and wrote the manuscript. $\mathrm{CAB}$ conceived the project, conducted the microarray experiments, annotated the gene list and conducted early Q-PCR. JMT provided advice about the experimental design and conducted bioinformatics analysis. EKB assisted with Figure design and edited the manuscript. EJR provided ES cell lines, supervised the project, provided grant support and finalised the manuscript. All authors read and approved the final manuscript.

\section{Additional material}

\section{Additional file 1}

Full list of genes mis-regulated in ES array. Data is divided into phase 1 and phase 2, as described in the materials and methods.

Click here for file

[http://www.biomedcentral.com/content/supplementary/1471213X-9-54-S1.XLS]

\section{Additional file 2}

Full list of genes mis-regulated in EB array.

Click here for file

[http://www.biomedcentral.com/content/supplementary/1471-

213X-9-54-S2.XLS]

\section{Additional file 3}

Laminin and Collagen IV staining of suspension EBs and EB outgrowths. A. Day 4 wild-type and Smad4 null EBs grown for 2 days on fibronectin-coated $(25 \mathrm{~g} / \mathrm{ml})$ dishes. Smad4 mutant EBs express increased levels of Collagen IV B. Cryosections of day4, day 7 and day10 suspension EBs stained for laminin. Smad4 mutant EBs display increased basement membrane deposition beneath the outer endoderm layer. Click here for file

[http://www.biomedcentral.com/content/supplementary/1471213X-9-54-S3.PDF]

\section{Additional file 4}

Primers. Indicated is the gene name, forward and reverse primer sequence, expected product size and annealing temperature used for QPCR.

Click here for file

[http://www.biomedcentral.com/content/supplementary/1471213X-9-54-S4.DOC]

\section{Acknowledgements}

We thank Cordelia Langford and Peter Ellis of the Wellcome Trust Sanger Institute for performing the Illumina arrays, George Trichas and Shankar Srinivas for help with confocal imaging and Juan Carlos Lopez Baez for animal maintenance and genotyping assistance. This work was supported by a Programme Grant from the Wellcome Trust to EJR.

\section{References}

I. Schmierer B, Hill CS: TGFbeta-SMAD signal transduction: molecular specificity and functional flexibility. Nat Rev Mol Cell Biol 2007, 8:970-82. 
2. Massague J, Seoane J, Wotton D: Smad transcription factors. Genes Dev 2005, 19:2783-8I0.

3. Tam PP, Loebel DA: Gene function in mouse embryogenesis: get set for gastrulation. Nat Rev Genet 2007, 8:368-81.

4. Arnold SJ, Robertson EJ: Making a commitment: cell lineage allocation and axis patterning in the early mouse embryo. Nat Rev Mol Cell Biol 2009, 10:91-103.

5. Brennan J, Lu CC, Norris DP, Rodriguez TA, Beddington RS, Robertson E): Nodal signalling in the epiblast patterns the early mouse embryo. Nature 200I, 4I I:965-9.

6. Mesnard D, Guzman-Ayala M, Constam DB: Nodal specifies embryonic visceral endoderm and sustains pluripotent cells in the epiblast before overt axial patterning. Development 2006, I 33:2497-505.

7. Thomas $\mathrm{P}$, Beddington R: Anterior primitive endoderm may be responsible for patterning the anterior neural plate in the mouse embryo. Curr Biol 1996, 6:1487-96.

8. Perea-Gomez A, Vella FD, Shawlot W, Oulad-Abdelghani M, Chazaud C, Meno C, Pfister V, Chen L, Robertson E, Hamada H, et al.: Nodal antagonists in the anterior visceral endoderm prevent the formation of multiple primitive streaks. Dev Cell 2002, 3:745-56

9. Mishina Y, Suzuki A, Ueno N, Behringer RR: Bmpr encodes a type I bone morphogenetic protein receptor that is essential for gastrulation during mouse embryogenesis. Genes Dev 1995 9:3027-37.

10. Conlon FL, Lyons KM, Takaesu N, Barth KS, Kispert A, Herrmann B, Robertson EJ: A primary requirement for nodal in the formation and maintenance of the primitive streak in the mouse. Development 1994, 120:1919-28.

II. Dunn NR, Vincent SD, Oxburgh L, Robertson EJ, Bikoff EK: Combinatorial activities of Smad2 and Smad3 regulate mesoderm formation and patterning in the mouse embryo. Development 2004, 131:1717-28

12. Ben-Haim N, Lu C, Guzman-Ayala M, Pescatore L, Mesnard D, Bischofberger M, Naef F, Robertson EJ, Constam DB: The nodal precursor acting via activin receptors induces mesoderm by maintaining a source of its convertases and BMP4. Dev Cell 2006, II:313-23.

13. Vincent SD, Dunn NR, Hayashi S, Norris DP, Robertson E): Cell fate decisions within the mouse organizer are governed by graded Nodal signals. Genes Dev 2003, 17:1646-62.

14. Chang H, Brown CW, Matzuk MM: Genetic analysis of the mammalian transforming growth factor-beta superfamily. Endocr Rev 2002, 23:787-823.

15. Zhao GQ: Consequences of knocking out BMP signaling in the mouse. Genesis 2003, 35:43-56.

16. Arnold SJ, Maretto S, Islam A, Bikoff EK, Robertson E): Dosedependent Smad I, Smad5 and Smad8 signaling in the early mouse embryo. Dev Biol 2006, 296:104-18.

17. Sirard C, de la Pompa JL, Elia A, Itie A, Mirtsos C, Cheung A, Hahn S, Wakeham A, Schwartz L, Kern SE, et al.: The tumor suppressor gene Smad4/Dpc4 is required for gastrulation and later for anterior development of the mouse embryo. Genes Dev 1998 , 1 2:107-19.

18. Yang $X, \mathrm{Li} \mathrm{C}, \mathrm{Xu} X$, Deng C: The tumor suppressor SMAD4/ DPC4 is essential for epiblast proliferation and mesoderm induction in mice. Proc Natl Acad Sci USA 1998, 95:3667-72.

19. Chu GC, Dunn NR, Anderson DC, Oxburgh L, Robertson E): Differential requirements for Smad4 in TGFbeta-dependent patterning of the early mouse embryo. Development 2004, | 31:3501-12.

20. Robertson E, Bradley A, Kuehn M, Evans M: Germ-line transmission of genes introduced into cultured pluripotential cells by retroviral vector. Nature 1986, 323:445-8.

21. Livak KJ, Schmittgen TD: Analysis of relative gene expression data using real-time quantitative PCR and the 2(-Delta Delta C(T)) Method. Methods 200I, 25:402-8.

22. Lopez-Rovira T, Chalaux E, Massague J, Rosa JL, Ventura F: Direct binding of Smad I and Smad4 to two distinct motifs mediates bone morphogenetic protein-specific transcriptional activation of Id I gene. J Biol Chem 2002, 277:3 I76-85.

23. Kang $Y, C$ Chen $C R$, Massague J: A self-enabling TGFbeta response coupled to stress signaling: Smad engages stress response factor ATF3 for IdI repression in epithelial cells. Mol Cell 2003, II:915-26.
24. Jia Q, McDill BW, Li SZ, Deng C, Chang CP, Chen F: Smad signaling in the neural crest regulates cardiac outflow tract remodeling through cell autonomous and non-cell autonomous effects. Dev Biol 2007, 3 I I: I72-84.

25. Ying QL, Nichols J, Chambers I, Smith A: BMP induction of Id proteins suppresses differentiation and sustains embryonic stem cell self-renewal in collaboration with STAT3. Cell 2003, I I 5:28I-92

26. Hollnagel A, Oehlmann V, Heymer J, Ruther U, Nordheim A: Id genes are direct targets of bone morphogenetic protein induction in embryonic stem cells. J Biol Chem 1999, 274: 19838-45.

27. Chen C, Shen MM: Two modes by which Lefty proteins inhibit nodal signaling. Curr Biol 2004, I 4:6 I8-24.

28. Cheng SK, Olale F, Brivanlou AH, Schier AF: Lefty blocks a subset of TGFbeta signals by antagonizing EGF-CFC coreceptors. PLOS Biol 2004, 2:E30.

29. Branford WW, Yost HJ: Lefty-dependent inhibition of Nodaland Wnt-responsive organizer gene expression is essential for normal gastrulation. Curr Biol 2002, | 2:2|36-4|.

30. Meno C, Gritsman K, Ohishi S, Ohfuji Y, Heckscher E, Mochida K, Shimono A, Kondoh H, Talbot WS, Robertson EJ, et al: Mouse Lefty 2 and zebrafish antivin are feedback inhibitors of nodal signaling during vertebrate gastrulation. Mol Cell 1999, 4:287-98.

31. Subramanian G, Schwarz RE, Higgins L, McEnroe G, Chakravarty S, Dugar $S$, Reiss $M$ : Targeting endogenous transforming growth factor beta receptor signaling in SMAD4-deficient human pancreatic carcinoma cells inhibits their invasive phenotypel. Cancer Res 2004, 64:5200-II.

32. Levy L, Hill CS: Smad4 dependency defines two classes of transforming growth factor \{beta\} (TGF-\{beta\}) target genes and distinguishes TGF-\{beta\}-induced epithelial-mesenchymal transition from its antiproliferative and migratory responses. Mol Cell Biol 2005, 25:8108-25.

33. Cinelli $P$, Casanova EA, Uhlig S, Lochmatter P, Matsuda T, Yokota T, Rulicke $T$, Ledermann $B$, Burki K: Expression profiling in transgenic FVB/N embryonic stem cells overexpressing STAT3. BMC Dev Biol 2008, 8:57.

34. Kaji K, Nichols J, Hendrich B: Mbd3, a component of the NuRD co-repressor complex, is required for development of pluripotent cells. Development 2007, I 34: I | 23-32.

35. Yang L, Cai CL, Lin L, Qyang Y, Chung C, Monteiro RM, Mummery $\mathrm{CL}$, Fishman $\mathrm{Gl}$, Cogen A, Evans S: IsII Cre reveals a common Bmp pathway in heart and limb development. Development 2006, I33: 1575-85.

36. Ivanova N, Dobrin R, Lu R, Kotenko I, Levorse J, DeCoste C, Schafer $X$, Lun $Y$, Lemischka IR: Dissecting self-renewal in stem cells with RNA interference. Nature 2006, 442:533-8.

37. Falco G, Lee SL, Stanghellini I, Bassey UC, Hamatani T, Ko MS: Zscan4: a novel gene expressed exclusively in late 2-cell embryos and embryonic stem cells. Dev Biol 2007, 307:539-50.

38. Storm MP, Kumpfmueller B, Thompson B, Kolde R, Vilo J, Hummel $\mathrm{O}$, Schulz $\mathrm{H}$, Welham MJ: Characterization of the phosphoinositide 3-kinase-dependent transcriptome in murine embryonic stem cells: identification of novel regulators of pluripotency. Stem Cells 2009, 27:764-75.

39. Lin TP, Labosky PA, Grabel LB, Kozak CA, Pitman JL, Kleeman J, MacLeod CL: The Pem homeobox gene is $\mathbf{X}$-linked and exclusively expressed in extraembryonic tissues during early murine development. Dev Biol 1994, 166:170-9.

40. Fan Y, Melhem MF, Chaillet JR: Forced expression of the homeobox-containing gene Pem blocks differentiation of embryonic stem cells. Dev Biol 1999, 21 0:48I-96.

4I. Storre J, Schafer A, Reichert N, Barbero JL, Hauser S, Eilers M, Gaubatz S: Silencing of the meiotic genes SMCIbeta and STAG3 in somatic cells by E2F6. B Biol Chem 2005, 280:41380-6.

42. Pohlers M, Truss M, Frede U, Scholz A, Strehle M, Kuban RJ, Hoffmann B, Morkel M, Birchmeier C, Hagemeier C: A role for E2F6 in the restriction of male-germ-cell-specific gene expression. Curr Biol 2005, I 5: 1051-7.

43. Sherwood RI, Jitianu C, Cleaver O, Shaywitz DA, Lamenzo JO, Chen $\mathrm{AE}$, Golub TR, Melton DA: Prospective isolation and global gene expression analysis of definitive and visceral endoderm. Dev Biol 2007, 304:541-55. 
44. Yang DH, Smith ER, Roland IH, Sheng Z, He J, Martin WD, Hamilton TC, Lambeth JD, Xu XX: Disabled-2 is essential for endodermal cell positioning and structure formation during mouse embryogenesis. Dev Biol 2002, 25 I:27-44.

45. Rula ME, Cai KQ, Moore R, Yang DH, Staub CM, Capo-Chichi CD, Jablonski SA, Howe PH, Smith ER, Xu XX: Cell autonomous sorting and surface positioning in the formation of primitive endoderm in embryoid bodies. Genesis 2007, 45:327-38.

46. Morrisey EE, Musco S, Chen MY, Lu MM, Leiden JM, Parmacek MS: The gene encoding the mitogen-responsive phosphoprotein Dab2 is differentially regulated by GATA-6 and GATA-4 in the visceral endoderm. / Biol Chem 2000, 275:19949-54.

47. Morrisey EE, Tang Z, Sigrist K, Lu MM, Jiang F, Ip HS, Parmacek MS: GATA6 regulates HNF4 and is required for differentiation of visceral endoderm in the mouse embryo. Genes Dev 1998, 1 2:3579-90

48. Koutsourakis M, Langeveld A, Patient R, Beddington R, Grosveld F: The transcription factor GATA6 is essential for early extraembryonic development. Development 1999, I 26:723-32.

49. Poirier F, Chan CT, Timmons PM, Robertson EJ, Evans MJ, Rigby PW: The murine $\mathrm{HI} 9$ gene is activated during embryonic stem cell differentiation in vitro and at the time of implantation in the developing embryo. Development |99|, I |3:| I05-I4.

50. Shibanuma M, Mashimo J, Kuroki T, Nose K: Characterization of the TGF beta I-inducible hic-5 gene that encodes a putative novel zinc finger protein and its possible involvement in cellular senescence. J Biol Chem 1994, 269:26767-74

5I. Brown MC, Turner CE: Paxillin: adapting to change. Physiol Rev 2004, 84:1315-39.

52. Nishiya N, Tachibana K, Shibanuma M, Mashimo JI, Nose K: Hic-5reduced cell spreading on fibronectin: competitive effects between paxillin and Hic-5 through interaction with focal adhesion kinase. Mol Cell Biol 200I, 21 :5332-45.

53. Tumbarello DA, Turner CE: Hic-5 contributes to epithelial-mesenchymal transformation through a RhoA/ROCK-dependent pathway. J Cell Physiol 2007, 2 I I:736-47.

54. Grabel LB, Watts TD: The role of extracellular matrix in the migration and differentiation of parietal endoderm from teratocarcinoma embryoid bodies. J Cell Biol 1987, 105:44I-8.

55. Nichols J, Zevnik B, Anastassiadis K, Niwa H, Klewe-Nebenius D Chambers I, Scholer H, Smith A: Formation of pluripotent stem cells in the mammalian embryo depends on the POU transcription factor Oct4. Cell 1998, 95:379-9|.

56. Niwa H, Miyazaki J, Smith AG: Quantitative expression of Oct-3/ 4 defines differentiation, dedifferentiation or self-renewal of ES cells. Nat Genet 2000, 24:372-6.

57. Page-McCaw A, Ewald AJ, Werb Z: Matrix metalloproteinases and the regulation of tissue remodelling. Nat Rev Mol Cell Biol 2007, 8:22I-33.

58. Itoh Y, Seiki M: MTI-MMP: a potent modifier of pericellular microenvironment. J Cell Physiol 2006, 206: I-8.

59. Koinuma D, Tsutsumi S, Kamimura N, Taniguchi H, Miyazawa $\mathrm{K}$ Sunamura M, Imamura T, Miyazono K, Aburatani H: Chromatin immunoprecipitation on microarray analysis of Smad2/3 binding sites reveals roles of ETSI and TFAP2A in transforming growth factor beta signaling. Mol Cell Biol 2009, 29: $172-86$.

60. Jazag A, ljichi H, Kanai F, Imamura T, Guleng B, Ohta M, Imamura J, Tanaka $Y$, Tateishi $K$, lkenoue $T$, et al.: Smad4 silencing in pancreatic cancer cell lines using stable RNA interference and gene expression profiles induced by transforming growth factorbeta. Oncogene 2005, 24:662-7I.

61. Yu J, Zhang L, Chen A, Xiang G, Wang Y, Wu J, Mitchelson K, Cheng J, Zhou $Y$ : Identification of the gene transcription and apoptosis mediated by TGF-beta-Smad2/3-Smad4 signaling. J Cell Physiol 2008, 21 5:422-33.

62. Sirard C Kim S, Mirtsos C. Tadich P, Hoodless PA, Itie A, Maxson R Wrana JL, Mak TW: Targeted disruption in murine cells reveals variable requirement for $\mathrm{Smad} 4$ in transforming growth factor beta-related signaling. Biol Chem 2000, 275:2063-70.

63. James D, Levine AJ, Besser D, Hemmati-Brivanlou A: TGFbeta/ activin/nodal signaling is necessary for the maintenance of pluripotency in human embryonic stem cells. Development 2005, I 32: 1 273-82.

64. Ogawa K, Saito A, Matsui H, Suzuki H, Ohtsuka S, Shimosato D, Morishita Y, Watabe T, Niwa H, Miyazono K: Activin-Nodal sign- aling is involved in propagation of mouse embryonic stem cells. J Cell Sci 2007, 120:55-65.

65. Biondi CA, Das D, Howell M, Islam A, Bikoff EK, Hill CS, Robertson EJ: Mice develop normally in the absence of Smad4 nucleocytoplasmic shuttling. Biochem J 2007, 404:235-45.

66. Lin X, Duan X, Liang YY, Su Y, Wrighton KH, Long J, Hu M, Davis CM, Wang J, Brunicardi FC, et al.: PPMIA functions as a Smad phosphatase to terminate TGFbeta signaling. Cell 2006, 125:9|5-28.

67. Dai F, Lin X, Chang C, Feng XH: Nuclear export of Smad2 and Smad3 by RanBP3 facilitates termination of TGF-beta signaling. Dev Cell 2009, I6:345-57.

68. Wang J, Xu N, Feng X, Hou N, Zhang J, Cheng X, Chen Y, Zhang Y, Yang X: Targeted disruption of Smad4 in cardiomyocytes results in cardiac hypertrophy and heart failure. Circ Res 2005, 97:821-8.

69. Kunath T, Saba-El-Leil MK, Almousailleakh M, Wray J, Meloche S, Smith A: FGF stimulation of the Erk I/2 signalling cascade triggers transition of pluripotent embryonic stem cells from selfrenewal to lineage commitment. Development 2007 I34:2895-902.

70. Bortvin A, Eggan K, Skaletsky H, Akutsu H, Berry DL, Yanagimachi R, Page DC, Jaenisch R: Incomplete reactivation of Oct4-related genes in mouse embryos cloned from somatic nuclei. Development 2003, 130:1673-80.

7I. Derbinski J, Schulte A, Kyewski B, Klein L: Promiscuous gene expression in medullary thymic epithelial cells mirrors the peripheral self. Nat Immunol 200I, 2:1032-9.

72. Schaller CE, Wang CL, Beck-Engeser G, Goss L, Scott HS, Anderson MS, Wabl M: Expression of Aire and the early wave of apoptosis in spermatogenesis. J Immunol 2008, 1 80:1338-43.

73. Gillard GO, Dooley J, Erickson M, Peltonen L, Farr AG: Airedependent alterations in medullary thymic epithelium indicate a role for Aire in thymic epithelial differentiation. J Immunol 2007, I78:3007-I5.

74. Pfister S, Steiner KA, Tam PP: Gene expression pattern and progression of embryogenesis in the immediate post-implantation period of mouse development. Gene Expr Patterns 2007, 7:558-73.

75. Li S, Edgar D, Fassler R, Wadsworth W, Yurchenco PD: The role of laminin in embryonic cell polarization and tissue organization. Dev Cell 2003, 4:6I3-24.

76. Smyth N, Vatansever HS, Murray P, Meyer M, Frie C, Paulsson M, Edgar D: Absence of basement membranes after targeting the LAMCI gene results in embryonic lethality due to failure of endoderm differentiation. J Cell Biol 1999, 144:15I-60.

77. Miner JH, Li C, Mudd JL, Go G, Sutherland AE: Compositional and structural requirements for laminin and basement membranes during mouse embryo implantation and gastrulation. Development 2004, I 3 I:2247-56.

78. Alpy F, Jivkov I, Sorokin L, Klein A, Arnold C, Huss Y, Kedinger M, Simon-Assmann P, Lefebvre O: Generation of a conditionally null allele of the laminin alphal gene. Genesis 2005, 43:59-70.

79. Das SK, Yano S, Wang J, Edwards DR, Nagase H, Dey SK: Expression of matrix metalloproteinases and tissue inhibitors of metalloproteinases in the mouse uterus during the periimplantation period. Dev Genet I997, 2 I:44-54.

80. Brenner CA, Adler RR, Rappolee DA, Pedersen RA, Werb Z: Genes for extracellular-matrix-degrading metalloproteinases and their inhibitor, TIMP, are expressed during early mammalian development. Genes Dev 1989, 3:848-59.

8I. Adler RR, Brenner CA, Werb Z: Expression of extracellular matrix-degrading metalloproteinases and metalloproteinase inhibitors is developmentally regulated during endoderm differentiation of embryonal carcinoma cells. Development 1990, I 10:21 I-20.

82. Oh J, Takahashi R, Adachi E, Kondo S, Kuratomi S, Noma A, Alexander DB, Motoda H, Okada A, Seiki M, et al.: Mutations in two matrix metalloproteinase genes, MMP-2 and MTI-MMP, are synthetic lethal in mice. Oncogene 2004, 23:504I-8.

83. Yu Q, Stamenkovic l: Cell surface-localized matrix metalloproteinase-9 proteolytically activates TGF-beta and promotes tumor invasion and angiogenesis. Genes Dev 2000, 14:163-76.

84. Kajita M, Itoh Y, Chiba T, Mori H, Okada A, Kinoh H, Seiki M: Membrane-type I matrix metalloproteinase cleaves CD44 and promotes cell migration. J Cell Biol 200I, 1 53:893-904. 
85. Li X, Talts U, Talts JF, Arman E, Ekblom P, Lonai P: Akt/PKB regulates laminin and collagen IV isotypes of the basement membrane. Proc Natl Acad Sci USA 200I, 98: 144I6-2I.

86. Robertson Ej: Embryo-derived stem cell lines. In Teratocarcinoma and Embryonic Stem Cells: A Practical Approach Edited by: Robertson EJ. Oxford, UK: IRL Press; I 987:7I-I I2.

87. Huber $W$, von Heydebreck A, Sultmann H, Poustka A, Vingron M: Variance stabilization applied to microarray data calibration and to the quantification of differential expression. Bioinformatics 2002, I 8(SuppI I):S96-104.

88. Nagy A, Gertsenstein M, Vintersten K, Behringer R: Manipulating The Mouse Embryo: A Laboratory Manual. 3rd edition. Cold Spring Harbor, NY: Cold Spring Harbor Laboratory Press; 2003.

89. Wang $X$, Harris RE, Bayston LJ, Ashe HL: Type IV collagens regulate BMP signalling in Drosophila. Nature 2008, 455:72-7.

Publish with Bio Med Central and every scientist can read your work free of charge

"BioMed Central will be the most significant development for disseminating the results of biomedical research in our lifetime."

Sir Paul Nurse, Cancer Research UK

Your research papers will be:

- available free of charge to the entire biomedical community

- peer reviewed and published immediately upon acceptance

- cited in PubMed and archived on PubMed Central

- yours - you keep the copyright

Submit your manuscript here:

http://www.biomedcentral.com/info/publishing_adv.asp
BioMedcentral 